Number 3

\title{
GAMBARAN KADAR HbA1C PADA PASIEN DIABETES MELITUS TIPE 2 DI RSUD WANGAYA
}

\author{
Hurin Nuril Karimah', I Gusti Agung Dewi Sarihati², Nur Habibah ${ }^{3}$ \\ 1.2.3 Jurusan Analis Kesehatan Poltekkes Denpasar \\ Jl. Sanitasi No 1Sidakarya Denpasar, telp (0361)710527 \\ Corresponding author: I Gusti Agung Dewi Sarihati, email: dewisarihati@gmail.com
}

\begin{abstract}
Background: Diabetes mellitus (DM) is a degenerative chronic disease and characterized by the increasing of normal blood sugar level which causes high level of glucosuria. The measurement of HbAlc is an accurate way to determine high blood sugar levels over the past two to three months.

Objective:The aim of this study was to determine the level of HbAlc in Diabetes mellitus Type 2 patients at the RSUD Wangaya Denpasar City.

Methods : This research is a descriptive study and the obtained data will be described using tables and narations. Primary data were obtained by conducting interviews and laboratory examination. The respondents were 30 patients of Diabetes mellitus type 2 who performed HbAlc examination at Wangaya Hospital.

Results: The results of this study showed $40 \%$ of respondents with HbAlc controlled and $60 \%$ uncontrolled. HbAlc controlled with normal BMI 40\%, food intake according to recommended $40 \%$, exercising regularly $23.3 \%$ regularly consuming antidiabetic drugs $40 \%$. HbAlc is not controlled by a normal BMI 33.3\% exercise regularly 3.3\% food intake according to the recommended $30 \%$, regular antidiabetic consumption is $40 \%$.

Conclusion : From these data it can be concluded that the respondents with controlled HbAlc all had normal BMI, recommended food intake, regularly consumed antidiabetic and most exercise routines.
\end{abstract}

Keywords : HbAlc, Diabetes mellitus Type 2.

\section{PENDAHULUAN}

Pola penyakit di Indonesia telah mengalami pergeseran yang ditandai dengan transisi epidemiologi. Secara garis besar transisi epidemiologi ditandai dengan perubahan pola penyakit dan kematian yang semula didominasi oleh penyakit infeksi beralih ke penyakit non infeksi atau penyakit tidak menular seperti penyakit jantung, hipertensi, diabetes, kegemukan dan lainnya. Kontributor utama terjadinya penyakit kronis adalah pola hidup yang tidak sehat seperti kebiasaan merokok, minum alkohol berlebihan, pola makan yang

Meditory | ISSN Online : 2549-1520, ISSN Cetak : 2338 - 1159, Vol. 6, No. 2, Desember 2018 HIm. 88 - 98, http://ejournal.poltekkes-denpasar.ac.id/index.php/M 
Hurin Nuril Karimah, dkk., Gambaran Kadar Hba1c Pada Pasien Diabetes Melitus Tipe 2 Di RSUD Wangaya

tidak baik dan obesitas, aktivitas fisik

yang kurang, stres, dan pencemaran lingkungan ${ }^{1}$.

Diabetes melitus (DM) merupakan salah satu penyakit degeneratif menahun yang mengalami peningkatan tajam dan menduduki peringkat keempat sebagai epidemik dunia penyebabkan kematian. Penyakit diabetes melitus ini ditandai dengan naiknya kadar glukosa darah puasa (hiperglikemia) dan mengakibatkan tingginya kadar glukosa darah dalam urin $^{2}$.

Menurut WHO 2007, Indonesia masuk ke dalam sepuluh negara dengan jumlah kasus diabetes melitus terbanyak di dunia. Berdasarkan laporan hasil Riset Kesehatan Dasar menunjukkan bahwa prevalensi DM pada tahun 2000 sebanyak 5,6 juta dan diprediksi akan mengalami peningkatan pertahun sebanyak 8,2 juta dan pada tahun 2030 sebanyak 21,3 juta. Dengan angka tersebut Indonesia menempati peringkat ke-5 di dunia, atau naik dua peringkat dibandingkan tahun 2013 yang menempati peringkat ke-7 di dunia ${ }^{3}$ Prevalensi DM terdiagnosis di Indonesia sebesar 2,1\%. Prevalensi diabetes yang terdiagnosis dokter tertinggi terdapat di DI Yogyakarta $(2,6 \%)$, DKI Jakarta (2,5\%), Sulawesi Utara $(2,4 \%)$, Kalimantan Timur $(2,3 \%)$, dan Bali (1,3\%). Berdasarkan Laporan hasil Riset Kesehatan Dasar (Riskesdas) di Bali tahun 2013 oleh Dinas Kesehatan, prevalensi DM di Bali tertinggi berada di daerah Jembrana (1,9\%), Buleleng (1,7\%), Tabanan dan Klungkung (1,5\%), dan Kota Denpasar (1,4\%). Kunjungan pasien DM di Puskesmas I Denpasar Utara meningkat yaitu sebanyak 1630 kunjungan dengan $85 \%$ jumlah kunjungan adalah pasien dengan DM tipe II yaitu sebanyak 1387 kunjungan 4.

Tujuan dari pelayanan kasus DM di Rumah Sakit tidak hanya untuk pengobatan, namun juga untuk pemeriksaan laboratorium, penyuluhan kesehatan masyarakat, usaha peningkatan gizi, pecatatan dan 
Hurin Nuril Karimah, dkk., Gambaran Kadar Hba1c Pada Pasien Diabetes Melitus Tipe 2 Di RSUD Wangaya

pelaporan, serta dilakukannya kegiatan diluar gedung melalui kegiatan pokok perawatan kesehatan masyarakat dan pembinaan peran serta masyarakat dibawah satu koordinasi ${ }^{5}$. Salah satu pemeriksaan laboratorium yang dilakukan adalah pemeriksaan $\mathrm{Hb}$ A1c.

HbAlc merupakan salah satu hemoglobin terglikasi dan tersubfraksi yang dibentuk oleh pelekatan berbagai glukosa ke molekul HbA (hemoglobin pada usia dewasa) yang akan meningkat dengan konsentrasi glukosa dalam darah rata-rata. Kadar $\mathrm{HbA1c}$ stabil berdasarkan rentang umur eritrosit sekitar 100 sampai 120 hari. Sehingga, HbAlc mencerminkan kadar glukosa darah rata-rata selama 2 sampai 3 bulan terakhir ${ }^{6}$. HbA1c merupakan pemeriksaan tunggal terbaik untuk menilai risiko terhadap kerusakan jaringan yang disebabkan oleh tingginya kadar gula darah ${ }^{7}$.

Kontrol glikemik yang optimal sangatlah penting untuk mencegah komplikasi yang timbul pada pasien DM, namun di Indonesia target pencapaian kontrol glikemik belum tercapai salah satunya adalah $\mathrm{HbAlc}$ yang masih memiliki rata-rata $8 \% 7$. Sedangkan kadar $\mathrm{HbAlc}$ normal adalah $\leq 7 \%$ dengan menggunakan metode yang terstandarisasi oleh National Glycohaemoglobin Standarization Program (NGSP) ${ }^{8}$. Pencegahan dan pengelolaan yang tepat dapat menjadi acuan penatalaksanaan diabetes melitus melalui edukasi, terapi gizi medis/diet, aktifitas fisik, dan intervensi farmakologis/pengobatan ${ }^{5}$.

\section{METODE}

Jenis penelitian yang digunakan adalah penelitian deskriptif. Pengambilan sampel dan pemeriksaan terhadap sampel dilakukan di Laboratorium RSUD Wangaya dan dilaksanakan pada bulan Maret sampai Juni tahun 2018. Populasi dalam penelitian ini adalah pasien diabetes melitus tipe 2 yang melakukan pemeriksaan $\mathrm{HbA1c}$ di RSUD Wangaya. Sampel berjumlah 30 yang memenuhi Kriteria inklusi :Pasien DM tipe 2 dengan kadar GDP

Meditory | ISSN Online : 2549-1520, ISSN Cetak : 2338 - 1159, Vol. 6, No. 2, Desember 2018 HIm. 88 - 98, http://ejournal.poltekkes-denpasar.ac.id/index.php/M 
Hurin Nuril Karimah, dkk., Gambaran Kadar Hba1c Pada Pasien Diabetes Melitus Tipe 2 Di RSUD Wangaya

(Glukosa Darah Puasa) $>126 \mathrm{mg} / \mathrm{dL}$ berusia lebih dari 30 tahun.dan bersedia menjadi responden dengan menyetujui informed consent. Responden dinyatakan terkontrol bila pada pemeriksaan $\mathrm{HbA1c}$ nilainya $\leq$ $7 \%$ dan tidak terkontrol bila $>7 \%$.

\section{HASIL DAN PEMBAHASAN}

\section{Hasil}

Berdasarkan penelitian yang telah dilakukan, diketahui bahwa sebanyak $12(40 \%)$ dari 30 responden memiliki kadar HbA1c normal (rerata HbA1c $6,3 \%)$ dinyatakan terkontrol dan 18 (60\%) responden memiliki kadar $\mathrm{HbA1c}$ lebih dari normal (rerata HbAlc 11,9\%) dinyatakan tidak terkontrol.

a. Kadar HbAlc responden berdasarkan Indeks massa tubuh (IMT) Tabel 1 menunjukkan bahwa responden dengan $\mathrm{HbA1c}$ terkontrol sebanyak $40 \%$ dan seluruhnya memiliki IMT normal

Tabel 1

Kadar HbA1c Berdasarkan Indeks Massa Tubuh Responden

\begin{tabular}{lccccccc}
\hline & \multicolumn{9}{c}{$\mathrm{HbA1c}$} & \multicolumn{3}{c}{ Total } \\
\cline { 2 - 7 } & \multicolumn{2}{c}{ Terkontrol } & \multicolumn{2}{c}{ Tidak } & & \\
\cline { 2 - 7 } & $\mathrm{n}$ & $\%$ & $\mathrm{n}$ & $\%$ & $\mathrm{n}$ & $\%$ \\
\hline Underweight & 0 & 0 & 2 & 6,7 & 2 & 6,7 \\
Normal & 12 & 40 & 10 & 33,3 & 22 & 73,3 \\
Overweight & 0 & 0 & 6 & 20 & 6 & 20 \\
\hline Total & 12 & 40 & 18 & 60 & 30 & 100 \\
\hline
\end{tabular}

b. Kadar HbA1c responden berdasarkan rutin berolahraga
Hasil pemeriksaan kadar HbA1c responden terhadap rutin berolahraga disajikan pada Tabel 2.

Meditory | ISSN Online : 2549-1520, ISSN Cetak : 2338 - 1159, Vol. 6, No. 2, Desember 2018 HIm. 88 - 98, http://ejournal.poltekkes-denpasar.ac.id/index.php/M 
Hurin Nuril Karimah, dkk., Gambaran Kadar Hba1c Pada Pasien Diabetes Melitus Tipe 2 Di RSUD Wangaya

Tabel 2

Kadar Hba1c Responden Berdasarkan Rutin Berolahraga

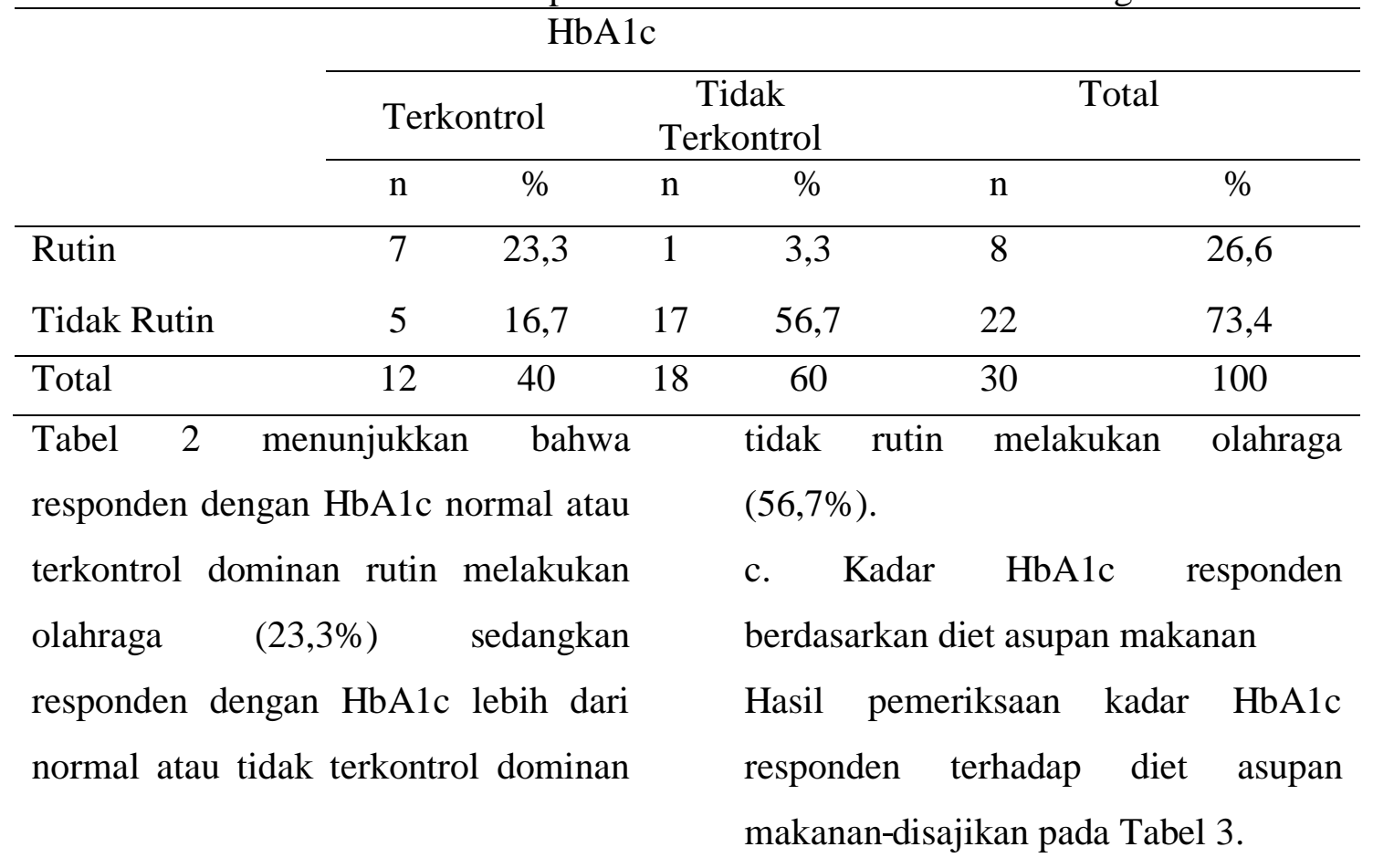

Tabel 3

Kadar HbA1c Responden Berdasarkan Diet Asupan Makanan

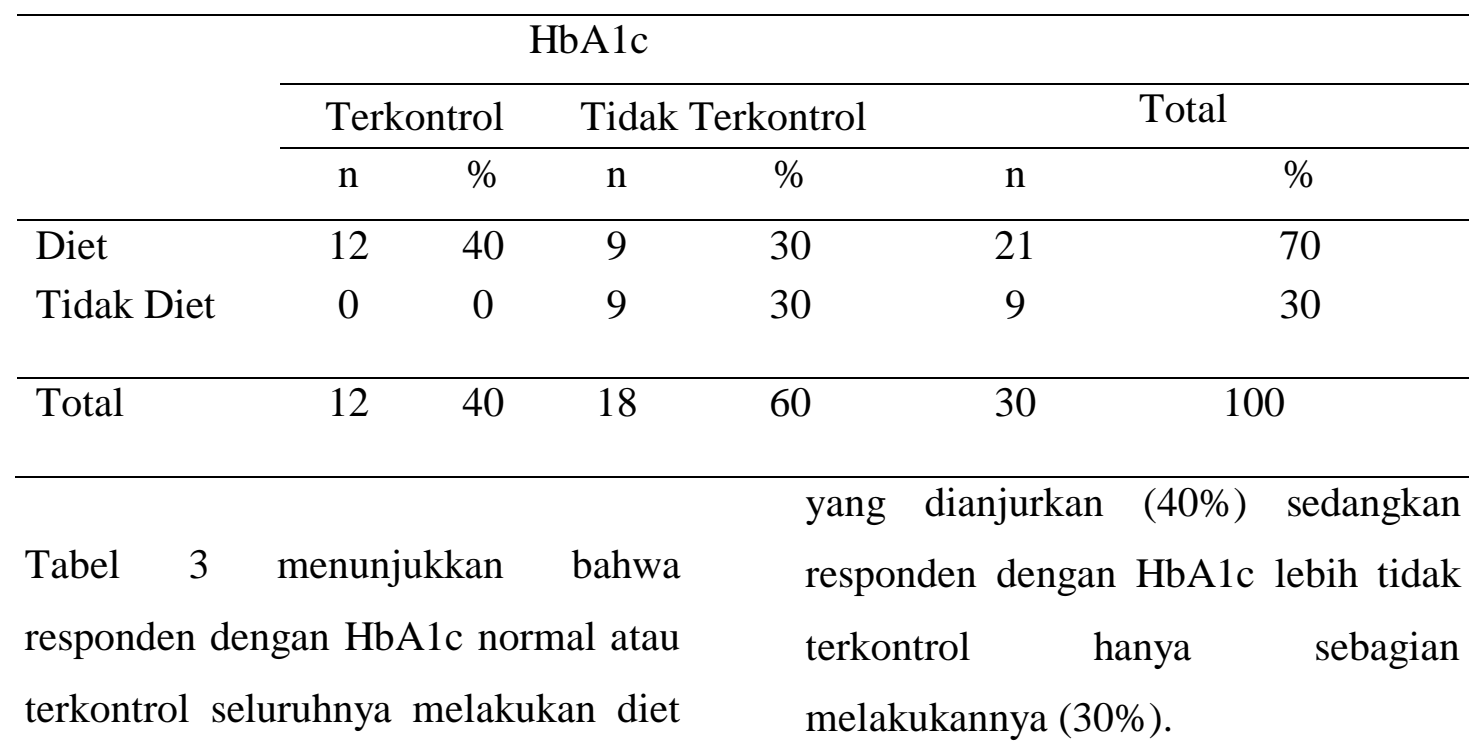

Meditory | ISSN Online : 2549-1520, ISSN Cetak : 2338 - 1159, Vol. 6, No. 2, Desember 2018 HIm. 88 - 98, http://ejournal.poltekkes-denpasar.ac.id/index.php/M 
Hurin Nuril Karimah, dkk., Gambaran Kadar Hba1c Pada Pasien Diabetes Melitus Tipe 2 Di RSUD Wangaya

d. Kadar HbA1c responden responden terhadap konsumsi obat berdasarkan konsumsi obat atau disajikan pada Tabel 4. insulin

Hasil pemeriksaan kadar HbA1c

Tabel

4.

Kadar Hba1c Responden Berdasarkan Konsumsi Obat Atau Insulin

\begin{tabular}{lcccccc}
\hline & \multicolumn{7}{c}{ HbA1c } & \multicolumn{2}{l}{ Total } \\
\cline { 2 - 7 } & \multicolumn{2}{c}{ Terkontrol } & \multicolumn{2}{c}{$\begin{array}{c}\text { Tidak } \\
\text { Terkontrol }\end{array}$} & \% \\
\cline { 2 - 7 } & $\mathrm{n}$ & $\%$ & $\mathrm{n}$ & $\%$ & $\mathrm{~N}$ & 60 \\
\hline Rutin & 12 & 40 & 6 & 20 & 18 & 40 \\
Tidak & 0 & 0 & 12 & 40 & 12 & 100 \\
Rutin & 12 & 40 & 18 & 60 & 30 & \\
\hline
\end{tabular}

Tabel 4 menunjukkan bahwa responden dengan HbA1c terkontrol (40\%) seluruhnya rutin mengkonsumsi obat sedangkan responden dengan $\mathrm{HbA1c}$ tidak terkontrol dominan tidak mengkonsumsi obat.

\section{Pembahasan}

HbA1c lebih mencerminkan kadar glukosa darah rata-rata selama 2 sampai 3 bulan sebelumnya daripada variasi kadar glukosa darah setiap hari. Pada penderita diabetes, kadar glukosa cenderung mudah meningkat dibandingkan kondisi normal, menurun dengan olah raga, meningkat setelah makan, apalagi setelah makan makanan manis, sehingga sulit untuk dikontrol. Pemeriksaan HbA1c dianjurkan untuk dilakukan setiap 3 bulan sekali atau 4 kali dalam setahun untuk mengetahui kualitas dari kontrol glukosa darah ${ }^{9}$.

\section{Kadar HbA1c pasien Diabetes melitus tipe 2 berdasarkan karakteristik subjek penelitian}

a. Indeks massa tubuh (IMT)

Diabetes melitus tipe 2 sangat erat kaitannya dengan obesitas. Pada penderita DM tipe 2, pancreas tetap

Meditory | ISSN Online : 2549-1520, ISSN Cetak : 2338 - 1159, Vol. 6, No. 2, Desember 2018 HIm. $88-98$, http://ejournal.poltekkes-denpasar.ac.id/index.php/M 
Hurin Nuril Karimah, dkk., Gambaran Kadar Hba1c Pada Pasien Diabetes Melitus Tipe 2 Di RSUD Wangaya

menghasilkan insulin dalam jumlah yang cukup untuk mempertahankan kadar glukosa darah pada tingkat normal, namun insulin tersebut tidak dapat bekerja maksimal untuk membawa glukosa ke dalam sel karena tingginya kadar kolesterol dan trigliserida pada orang yang mengalami obesitas. Adanya timbunan lemak pada tubuh dapat menurunkan sensitifitas terhadap kerja insulin pada otot dan hati sehingga dapat menyebabkan tubuh resisten terhadap insulin. Hal ini sesuai dengan hasil penelitian yang menunjukkan bahwa semua reponden overweight (Tabel 1) memiliki HBA1c tak terkontrol.

Namun demikian IMT normal dan underweight juga ditemukan pada responden dengan $\mathrm{HbAlc}$ tak terkontrol. Obesitas yang digambarkan dengan indeks massa tubuh tidak terlalu sensitif dalam menggambarkan gangguan metabolik yang terjadi. Obesitas sentral yang digambarkan oleh lingkar pinggang lebih sensitif dalam memprediksi gangguan metabolik. Pasien DM tidak terkontrol dapat mengalami penurunan berat badan tanpa sebab yang jelas. Akibatnya ketika pemeriksaan kadarHbA1c dilakukan, IMT pasien tidak overweight ${ }^{5}$.

b. Olahraga atau aktifitas fisik

Olahraga atau latihan jasmani merupakan salah satu pilar penatalaksanaan DM di samping edukasi, terapi gizi medis dan intervensi farmakologis. Pada saat seseorang melakukan latihan jasmani, pada tubuh akan terjadi peningkatan kebutuhan bahan bakar tubuh oleh otot yang aktif dan terjadi pula reaksi tubuh yang kompleks meliputi fungsi sirkulasi, metabolisme, dan susunan saraf otonom. Glukosa yang disimpan dalam otot dan hati sebagai glikogen cepat diakses untuk dipergunakan sebagai sumber energi pada latihan jasmani terutama pada beberapa atau permulaan latihan jasmani dimulai, sehingga setelah 30 menit akan terjadi penurunan kadar glukosa darahnya dibanding sebelum latihan jasmani ${ }^{10}$. Sedangkan kurangnya aktivitas fisik menyebabkan kurangnya pembakaran 
Hurin Nuril Karimah, dkk., Gambaran Kadar Hba1c Pada Pasien Diabetes Melitus Tipe 2 Di RSUD Wangaya

energi oleh tubuh sehingga kelebihan energi dalam tubuh akan disimpan dalam bentuk lemak dalam tubuh ${ }^{11}$.

c. Diet asupan makanan

Makanan diperlukan sebagai bahan bakar dalam pembentukan ATP. Selama pencernaan, banyak zat gizi yang diabsorpsi untuk memenuhi kebutuhan energi tubuh sampai makanan berikutnya. Di dalam makanan yang dikonsumsi, terkandung karbohidrat, lemak, dan protein. Kadar gula darah sebagian tercantum pada apa yang dimakan dan oleh karenanya sewaktu makan diperlukan adanya keseimbangan diet. Mempertahankaan kadar gula darah agar mendekati nilai normal dapat dilakukan dengan asupan makanan yang seimbang sesuai dengan kebutuhan. Perencanaan makanan merupakan salah satu pilar pengelolaan diabetes karena pada tubuh pasien Diabetes melitus memiliki kemampuan yang terbatas untuk mengatur metabolisme hidrat arang. Jika toleransi hidrat arang dilampaui, pasien akan mengalami peningkatan kadar glukosa dalam darah yang meningkatkan glycosuria. Glycosuria akan menyebabkan diuresis osmotik, yang menimbulkan kehilangan air dan elektrolite-seperti sodium, potassium, kalsium, magnesium, fosfat dan klorida. Dehidrasi, bila terjadi secara hebat, akan menimbulkan uremia pra renal dan dapat menimbulkan shock hypovolemik ${ }^{12}$.

d. Konsumsi obat atau insulin Terapi farmakologi dilakukan dengan pemberian obat antidiabetik, baik berupa obat antidiabetik oral maupun insulin. Terapi farmakologi pada prinsipnya diberikan jika terapi non farmakologi yang telah dilakukan tidak dapat mengendalikan kadar gula darah hingga mendekati batas kadar normal. Akan tetapi pemberian terapi ini tetap tidak meninggalkan terapi non farmakologis yang telah diterapkan sebelumnya ${ }^{13}$. Kepatuhan minum obat memiliki kesempatan 4 kali lebih baik untuk berhasil dalam pengelolaan DM tipe 2 dibandingkan dengan yang tidak patuh minum obat secara statistik bermakna ${ }^{14}$. 
Hurin Nuril Karimah, dkk., Gambaran Kadar Hba1c Pada Pasien Diabetes Melitus Tipe 2 Di RSUD Wangaya

Secara umum, obat antidiabetik bekerja meningkatkan sekresi insulin dan hanya efektif pada DM tipe-2 yang tidak kelebihan berat badan. Metformin yang termasuk golongan biguanid bekerja memperbaiki sensitivitas insulin, menghambat pembentukan glukosa dalam hati, dapat menurunkan kolesterol Low Density Lipoprotein (LDL) dan trigliserida serta berdaya menekan nafsu makan sehingga menjadi obat pilihan utama. Akarbose bekerja menghambat enzim glucosidase dengan demikian pembentukan dan penyerapan glukosa diperlambat, sehingga fluktuasi gula darah menjadi kecil $^{13}$.

\section{Simpulan}

Responden dengan kadar HbA1c tidak terkontrol lebih banyak (60\%) dibandingkan responden dengan kadar HbA1c terkontrol (40\%).

Responden dengan kadar HbA1c terkontrol seluruhnya memiliki IMT normal, diet asupan makanan secara teratur dan rutin mengkonsumsi obat insulin serta lebih banyak menerapkan kebiasaan rutin berolah raga. Sedangkan responden dengan $\mathrm{HbA1c}$ tidak terkontrol memiliki IMT underweight, normal dan overweight, sebagian besar tidak rutin berolah raga serta tidak rutin konsumsi obat antidiabetik.

\section{Pustaka}

1. Handajani A, Roosihermiatie B, Maryani H. Faktor-faktor yang berhubungan dengan pola kematian pada penyakit degeneratif di Indonesia. Bul Penelit Sist Kesehat. 2010; Vol 13(1):42-53. http://ejournal.litbang.depkes.go .id/index.php/hsr/article/view/27 55 .

2. Dwikayana, IM, Subawa, AAN, Sutirta Yasa I. Gambaran Hbalc Pasien Diabetes Melitus Tipe 2 Dengan Komplikasi Ulkus Kaki Diabetik Di Poliklinik Penyakit Dalam RSUP Sanglah Denpasar Periode April- September 2014. E-jurnal Med udayana. 2016;5(7):1-6. doi:https://doi.org/10.24922/eu m.v7i11

3. Kemkes RI. RISET KESEHATAN DASAR.; 2013. http://www.depkes.go.id/resour

Meditory | ISSN Online : 2549-1520, ISSN Cetak : 2338 - 1159, Vol. 6, No. 2, Desember 2018 HIm. 88 - 98, http://ejournal.poltekkes-denpasar.ac.id/index.php/M 
Hurin Nuril Karimah, dkk., Gambaran Kadar Hba1c Pada Pasien Diabetes Melitus Tipe 2 Di RSUD Wangaya

ces/download/general/Hasil

Riskesdas 2013.pdf.

4. RISKESDAS Bali. Riset Kesehatan Dasar Dalam Angka Provinsi Bali.; 2013. www.diskes.baliprov.go.id/files/ subdomain/diskes/.../riskesdas bali 2013.pdf. .

5. Sudoyo,

AW, Setiyohadi, B, Alwi I, Simadibrata, M, Setiati S. Buku Ajar Ilmu Penyakit Dalam Jilid II. 5th edn. Interna Publishing 2009

6. Bilouse R, Donelly R. Buku Pegangan Diabetes. 4th ed. (Bariid B, ed.). Jakarta: Bumi Medika; 2014.

7. Utomo MRS, Wungouw H, Marunduh S. Kadar HbA1c Pada Pasien Diabetes Melitus Tipe 2 di Puskesmas Bahu Kecamatan Malalayang. 2015;3(April):311.

https://ejournal.unsrat.ac.id/inde x.php/ebiomedik/article/view/66 20/6141.

8. Qurratuaeni. Faktorfaktor yang berhubungan dengan terkendalinya kadar gula darah pada pasien diabetes melitus di rumah sakit umum pusat (RSUP) fatmawati. In: Jakarta: Skripsi Fakultas Kedokteran dan Ilmu Kesehatan UIN Syarif Hidayatullah; 2009. repository.uinjkt.ac.id/dspace/bi tstream/.../597/1/ 92496QURRATUAENI-FKIK.pdf.

9. Paputungan SR, Sanusi $\mathrm{H}$, Bagian S, Metabolik E, Bagian D, Penyakit I. Peranan Pemeriksaan Hemoglobin A 1c pada Pengelolaan Diabetes Melitus. In: $C D K-220$. Vol 41. ; 2014:650-655.

10. Rachmawati O. Hubungan latihan jasmani terhadap kadar glukosa darah penderita diabetes melitus tipe2. In: Skripsi Fakultas Kedokteran Universitas Sebelas Maret. ; 2010.

11. Refa, S, Dewi N. The Correlation betwen $\mathrm{HbA1C}$ and Serum Lipid Level. J Kedokt Brawijaya. 2005;21:138-144.

12. Syahputra M. Diabetik Ketoacidisis. In: USU Digital Library. Bagian Biokimia Fakultas Kedokteran Universitas Sumatera Utara; 2003:1-14.

13. Inzucchi, S., Porte, D., Sherwin, R.S., Baron A. The Diabetes Melitus Manual,. Sixth Edit. USA McGraw-Hill: McGraw-Hill 2005.

14. Yoga S. U. A. Hubungan Antara 4 Pilar Pengelolaan Diabetes Melitus Dengan Keberhasilan

Meditory | ISSN Online : 2549-1520, ISSN Cetak : 2338-1159, Vol. 6, No. 2, Desember 2018 HIm. $88-98$, http://ejournal.poltekkes-denpasar.ac.id/index.php/M 
Hurin Nuril Karimah, dkk., Gambaran Kadar Hba1c Pada Pasien Diabetes Melitus Tipe 2 Di RSUD Wangaya

Pengelolaan Diabetes Melitus

Tipe 2. In: Program Pendidikan

Sarjana Kedokteran FK

Universitas Diponegoro.

Program Pendidikan Sarjana

Kedokteran FK Universitas

Diponegoro; 2011.

http://eprints.undip.ac.id/32797/

Meditory | ISSN Online : 2549-1520, ISSN Cetak : 2338 - 1159, Vol. 6, No. 2, Desember 2018 HIm. 88 - 98, http://ejournal.poltekkes-denpasar.ac.id/index.php/M 